\title{
Carbohydrate-Electrolyte Characteristics of Coconut Water from Different Varieties and Its Potential as Natural Isotonic Drink
}

\author{
Sari Intan Kailaku ${ }^{\# * 1}$, Andi Nur Alam Syah*, Risfaheri ${ }^{*}$, Budi Setiawan ${ }^{\# 2}$ and Ahmad Sulaeman ${ }^{\# 3}$ \\ ${ }^{\#}$ Department of Public Nutrition, Bogor Agricultural University, Bogor 16680, Indonesia \\ E-mail: 'sari.kaylaku@gmail.com, ${ }^{2}$ bsetiawan.ipb@gmail.com,3asulaeman06@gmail.com \\ *Indonesian Agency of Agricultural Research and Development, Indonesian Ministry of Agriculture, Bogor 16114, Indonesia \\ E-mail: ${ }^{4}$ ganesh.alam@gmail.com, ${ }^{5}$ risfaheribbpascapanen@yahoo.com
}

\begin{abstract}
Coconut water is known as a nutritious natural drink. It is not only considered functional, but also nutraceutical. Coconut water is widely used as isotonic drink or oral rehydration fluid, since it showed excellent rehydration index and blood glucose response in previous researches. The quality of isotonic drink is determined by its sugar content (as the source of carbohydrate) and electrolyte content. Moreover, its organoleptic properties should be able to stimulate the urge to spontaniously drink more. However, the processing of coconut water into isotonic drink usually applies ultra high or very low temperature which might deteriorate its nutrition value and organoleptic properties, causing the needs to use a considerable amount of food additives. There are plenty varieties of coconut in Indonesia, each produces different characteristics of coconut water. The objectives of this research are to compare the carbohydrate-electrolyte characteristics of coconut water, and also other essential characteristics from several varieties and to determine which variety is closest to the quality standard of isotonic drink. Therefore, isotonic drink can be developed with only minimum food additives. We compared Dalam Pangandaran, Genjah Salak and Hybrid PB121. The characteristics observed were total sugar, sucrose, glucose, fructose, potassium, sodium, magnesium, vitamin B1, vitamin B6 and vitamin C content, as well as pH, total soluble solids, clarity and colour. Coconut water obatined from Genjah (Dwarf) variety showed the more suitable characteristics for the development of isotonic drink. Thus the product can be developed by cold sterilitation process with minimum food additives.
\end{abstract}

Keywords - coconut water; isotonic drink; carbohydrate-electrolyte; coconut varieties

\section{INTRODUCTION}

Coconut water is rich with macronutrient and micronutrient content, i.e. carbohydrate, potassium, sodium, magnesium and chloride [1]. It is widely used as isotonic drink or oral rehydration fluid, because of its excellent rehydration index [2] and blood glucose response [3], therefore beneficial as after-exercise drink. Reference [4] showed that coconut water is beneficial for rehydration and physical performance recovery equal with that of carbohydrate-electrolyte sports drink, in exercised male subjects. Isotonic drink is carbonated or non carbonated beverage product used for fitness improvement, containing sugar, citric acid and minerals [5]. Not only as thirst quencher, it is also known as sports drink for athletes consumption, to maintain their hydration status, electrolyte and energy while exercising.

The increasing interest for natural products leads to the exploration of coconut water potential utilization in isotonic drink product development. The obstacle in developing coconut water-based product is its easily altered properties. Once a coconut is opened and the water is extracted from it, degradation will occur due to air contact, and the water will lose almost all of its organoleptic characteristics and some of its nutrient content, and starts to ferment. Thus, in only few hours after its extraction, coconut water will be cloudy, paleyellowish, sour and unappetizing tasteless, due to the activities of oxidase enzymes and microbial contamination [6]-[7].

The shelf-life of coconut water isotonic drink can be improved by ensuring the elimination of the causes of its quality degradation. There are several methods commonly used to preserve coconut water. Most commercial productions use high temperature which might cause the lost of nutrient content and its unique aroma and flavour [8].

Coconut water processing without using high temperature was introduced by FAO [9], i.e. microfiltration. This cold sterilisation process then was developed by [10] where the microfiultration membrane was replaced with ultrafiltration membrane. Unfortunately, the coconut water used in the 
research was from overly mature coconut and without varieties selection, thus its characteristics were unsuitable for the development of isotonic drink. The product development involved a considerably amount of the addition of sucrose, minerals and citric acids to obtain the standardized quality requirement. In order to increase the benefit and superiority of cold sterilisation process, the minimization of food additives can be done by using coconut water from a selected variety and nut age, with the closest characteristics to isotonic drink quality requirement.

Indonesia has the highest coconut diversity with the largest coconut plantation in the world [11]. Two large varieties of coconut are Dalam (Tall) and Genjah (Dwarf). Breeding activities has also produced Hybrid coconut from Tall and Dwarf varieties [12]. The characteristics are different among each varieties, and also among different nut age. The objective of this study are: (1) to characterise coconut water from Tall, Dwarf and Hybrid variety, and (2) to determine the suitable variety for product development of isotonic drink with cold sterilisation process.

\section{METHODS}

Analyzes were conducted at Food Analysis Laboratory, Indonesian Centre of Agricultural Postharvest Research and Development, Bogor, West Java. Coconut water was obtained from coconut varieties planted at Experimental Plantation, Indonesian Industrial Crops Research Institute, Sukabumi, West Java. Coconut age was pre-selected, i.e. 8-9 months, for the closest characteristics to isotonic drink quality requirement [13].

The characteristics being observed were total sugar, sucrose, glucose, fructose, potassium, sodium, magnesium, vitamin $\mathrm{B} 1$, vitamin $\mathrm{B} 6$ and vitamin $\mathrm{C}$ content, as well as total soluble solids (TSS), clarity and colour. Total sugar determination as in [14]. Sucrose, glucose, fructose, vitamin $\mathrm{C}$, vitamin B1 and vitamin B6 were analyzed using High Performance Liquid Chromatography [15]-[16]. Potassium, sodium and magnesium content were determined using Atomic Absorption Spectroscopy [17].

The characteristics of coconut water from all varieties were described. The difference between each variety were tested using One Way Anova with confidence level of $95 \%$. Sampling was done in three replications.

\section{RESULTS AND DISCUSSION}

The varieties being used in the study were Dalam Pangandaran (Tall), Genjah Salak (Dwarf) and Hibrida PB121 (Hybrid). The study used mature coconut water (8-9 months of age) for its more suitable characterisitics for the development of isotonic drink. Reference [13] compared the composition and physicochemical properties of different aged coconut water. They reported that the total sugar content tended to decrease during nut aging. Reference [12] reported that potassium content decreased during aging, while sodium content increased.

\section{A. Carbohydrate-Electrolyte Characteristics}

The results of sugar and mineral analyzes of coconut water from different varieties compared with the Indonesian National Standard (SNI) are presented in Table 1. Coconut water from Dwarf variety had the significantly highest total sugar, fructose and glucose content compared to Tall and Hybrid variety $(\mathrm{p}<0.05)$. This is an important characteristic for Dwarf as isotonic drink raw material. Beverages containing 6-8\% carbohydrate can maintain atheletes' blood glucose level and help them to achieve a good recovery rate [18]. This sufficient total sugar content will allow isotonic drink product development without additional sugar.

TABLE I

CARbohydrate-Electrolyte CONTENT OF COCONUT WATER

\begin{tabular}{|c|c|c|c|c|c|}
\hline \multirow[t]{2}{*}{ Components } & \multicolumn{3}{|c|}{ Variety } & \multirow{2}{*}{ p } & \multirow{2}{*}{ SNI* } \\
\hline & Dwarf & Tall & Hybrid & & \\
\hline $\begin{array}{l}\text { Total sugar } \\
(\%)\end{array}$ & $6.01 \pm 0.06^{\mathrm{c}}$ & $5.57 \pm 0.02^{\mathrm{b}}$ & $5.04 \pm 0.13^{\mathrm{a}}$ & 0.003 & $>5$ \\
\hline Sucrose $(\%)$ & $0.63 \pm 0.01^{b}$ & $0.50 \pm 0.00^{\mathrm{a}}$ & $0.85 \pm 0.42^{c}$ & 0.001 & \\
\hline Fructose $(\%)$ & $2.67 \pm 0.04^{b}$ & $2.56 \pm 0.04^{b}$ & $2.07 \pm 0.05^{\mathrm{a}}$ & 0.001 & \\
\hline Glucose (\%) & $2.71 \pm 0.01^{\mathrm{c}}$ & $2.51 \pm 0.01^{b}$ & $2.12 \pm 0.04^{\mathrm{a}}$ & 0.000 & \\
\hline $\begin{array}{l}\text { Potassium } \\
(\mathrm{mg} / \mathrm{kg})\end{array}$ & $\begin{array}{l}1497.40 \pm \\
43.73\end{array}$ & $\begin{array}{l}1567.96 \pm \\
351.77\end{array}$ & $\begin{array}{l}1504.00 \pm \\
128.76\end{array}$ & 0.939 & $\begin{array}{l}< \\
125- \\
175 \\
\end{array}$ \\
\hline $\begin{array}{l}\text { Sodium } \\
(\mathrm{mg} / \mathrm{kg})\end{array}$ & $\begin{array}{l}30.30 \pm \\
6.18\end{array}$ & $\begin{array}{l}37.33 \pm \\
6.18\end{array}$ & $\begin{array}{l}23.82 \pm \\
6.18\end{array}$ & 1.000 & $\begin{array}{l}< \\
800- \\
1000\end{array}$ \\
\hline $\begin{array}{l}\text { Magnesium } \\
(\mathrm{mg} / \mathrm{kg})\end{array}$ & $\begin{array}{l}95.40 \pm \\
3.88\end{array}$ & $\begin{array}{l}217.73 \pm \\
119.42\end{array}$ & $\begin{array}{l}24.30 \pm \\
4.42\end{array}$ & 0.142 & - \\
\hline
\end{tabular}

*Isotonic Drink Quality Requirement based on Indonesian National Standard (SNI) 01-4452-1998

Carbohydrate content in isotonic drink is needed for an immediate energy recharge [18] and glycogen replenishment, which had been spent when one is doing a strenuous physical activity [19].

Moreover, the existence of sufficient carbohydrate in isotonic drink will produce a palatable taste and stimulates the urge to drink spontaneously [20]. This is important to ensure an athlete to voluntarily drink an adequate amount of fluid. Coconut water has its own superiority compared to other isotonic drink because of its natural sweet taste due to the sugar content, along with the unique aroma and flavour, making it a favorite beverage for most people.

Strenous physical activity or exercise escalates electrolytes needs and can lead to dehydration. Therefore, rehydration fluid should be taken adequately to rehabilitate hydration status and should contain electrolytes to accelerate the rehydration process [19].

Mineral composition is an important factor that makes coconut water a natural rehydration fluid. High potassium content is effective in replenishing intracellular fluid, while high sodium content replenishes extracellular fluid [21].

The mineral contents of coconut water $(\mathrm{K}, \mathrm{Na}, \mathrm{Mg})$ were not significantly different in the three varieties (Table 1). The lower content of sodium compared to SNI can be a consideration in choosing a food additive to prolong shelflife. Choosing a material containing sodium, eg. sodium benzoate, to act both as preservative agent and fortifier, is more reasonable than other material eg. potassium sorbate which unnecessarily increases potassium content. 


\section{B. Vitamins Content}

Coconut water contains vitamins i.e. vitamin $\mathrm{C}, \mathrm{B} 1, \mathrm{~B} 2$, B3, B5, B6, folic acid, and B7 [22]. Vitamins contents are significantly different among the three varieties observed in this study $(\mathrm{p}<0.05)$. Dwarf variety had the highest vitamin $\mathrm{B} 1$, Tall variety contained highest vitamin B6, while Hybrid coconut had the highest vitamin $\mathrm{C}$ content (Table 2).

Although product quality standard for isotonic drink does not include vitamin content, the existence of vitamins in coconut water is nevertheless an advantage and is important in its role as isotonic drink. Beside its benefit as rehydration and energy fluid, isotonic drink should have free radical inhibition property. Oxidative stress can occur in overworked muscle tissues during exercise, hence it is beneficial for an athlete to consume rehydration fluid that contains antioxidants [20].

TABLE II

VITAMINS CONTENT OF COCONUT WATER

\begin{tabular}{|l|l|l|l|l|}
\hline \multirow{2}{*}{ Components } & \multicolumn{3}{|c|}{ Variety } & \multirow{2}{*}{ p } \\
\cline { 2 - 4 } & Dwarf & Tall & Hybrid & \\
\hline Vitamin B1 & $11.97 \pm 0.13^{\mathrm{c}}$ & $9.31 \pm 0.05^{\mathrm{b}}$ & $6.65 \pm 0.18^{\mathrm{a}}$ & 0.000 \\
\hline Vitamin B6 & $0.03 \pm 0.00^{\mathrm{a}}$ & $0.47 \pm 0.01^{\mathrm{b}}$ & $0.04 \pm 0.00^{\mathrm{a}}$ & 0.000 \\
\hline Vitamin C & $15.70 \pm 0.01^{\mathrm{b}}$ & $14.45 \pm 0.08^{\mathrm{a}}$ & $16.65 \pm 0.08^{\mathrm{c}}$ & 0.000 \\
\hline
\end{tabular}

\section{Physicochemical Properties}

Physicochemical properties are good indicators in estimating the suitability of coconut varieties for the production of coconut water as a beverage [23]. Dwarf coconut produced more water compared to Hybrid, but less than Tall coconut (Table 3). The water volume of Tall and Dwarf were considerably sufficient for a convenient mass production activity.

TSS and clarity level of the three varieties were significantly different $(\mathrm{p}<0.05)$, but $\mathrm{pH}$ value was not (Table 3). Coconut water from Dwarf variety had the highest TSS and clarity level. TSS generally represents the sweetness of coconut water [13]. Clarity of coconut water is one of its most important appearance attributes [24]. Consumers rate clear beverages as the most thirst-quenching and opaque beverages as the least [25].

TABLE III

PHYSICOCHEMICAL PROPERTIES OF COCONUT WATER

\begin{tabular}{|l|l|l|l|c|}
\hline \multirow{2}{*}{ Properties } & \multicolumn{3}{|c|}{ Variety } & p \\
\cline { 2 - 4 } & Dwarf & Tall & Hybrid & \\
\hline $\begin{array}{l}\text { Water volume } \\
\text { per nut (ml) }\end{array}$ & $485 \pm 7.07^{\mathrm{b}}$ & $632.5 \pm 10 / .61^{\mathrm{c}}$ & $330 \pm 28.28^{\mathrm{a}}$ & 0.001 \\
\hline $\mathrm{pH}$ & $6.02 \pm 0.13$ & $5.96 \pm 0.01$ & $5.83 \pm 0.08$ & 0.218 \\
\hline $\begin{array}{l}\text { Total soluble } \\
\text { solids ( }{ }^{\circ} \text { Brix) }\end{array}$ & $5.95 \pm 0.08^{\mathrm{b}}$ & $5.30 \pm 0.01^{\mathrm{a}}$ & $5.50 \pm 0.00^{\mathrm{a}}$ & 0.012 \\
\hline $\begin{array}{l}\text { Clarity (\% to } \\
\text { water) }\end{array}$ & $98.40 \pm 0.01^{\mathrm{c}}$ & $97.80 \pm 0.01^{\mathrm{b}}$ & $97.05 \pm 0.08^{\mathrm{a}}$ & 0.009 \\
\hline Colour & & & & \\
\hline $\mathrm{L}$ & $101.77 \pm 0.04^{\mathrm{c}}$ & $101.07 \pm 0.04^{\mathrm{b}}$ & $100.74 \pm 0.05^{\mathrm{a}}$ & 0.000 \\
\hline $\mathrm{a}$ & $-0.27 \pm 0.08^{\mathrm{b}}$ & $-0.21 \pm 0.08^{\mathrm{b}}$ & $-0.61 \pm 0.13^{\mathrm{a}}$ & 0.000 \\
\hline $\mathrm{b}$ & $0.03 \pm 0.05^{\mathrm{b}}$ & $-0.07 \pm 0.03^{\mathrm{a}}$ & $1.19 \pm 0.08^{\mathrm{c}}$ & 0.000 \\
\hline
\end{tabular}

L value (lightness) of coconut water decreases during storage despite microfiltration and addition of acid in product development [26]. L value of all the varieties in the study were above 100 due to its high clarity (not white) before storage. The high level of lightness and clarity of Dwarf coconut water was an advantage for its general appearance for future storage. Negative a values indicated a spectrum of greenish in all samples. Positive $b$ values showed that the samples had yellowish spectrum, except in Tall coconut water which showed bluish spectrum.

The characterization of coconut water samples from three different varieties showed that Dwarf variety may be recommended as raw material for isotonic drink product development for its closest characteristics to the quality standard. This result was resemblant with the conclusion in [23], where the synthesis of biochemical data showed that Dwarf coconut varieties, with their small nuts, high volume of water, high sugar contents and good organoleptic scores, were the most suitable cultivars to obtain sweet and tasty product.

\section{Processing Recommendation}

Cold sterilisation process are becoming more commonly used to extend the shelf-life of food and beverages product. Membrane technology is widely used in various area, i.e. biotechnology, pharmacy, food and beverages and gas isolation. Ultrafiltration is a filtration process using membrane, working in the pressure difference principal. Ultrafiltration process and pasteurization were proven equally effective in reducing enzyme activities in coconut water [27].

The advantages of using membrane technology are: (1) lower capital cost compared to convensional separation/filtration technology, (2) lower operational cost compared to centrifugation process, (3) easily scaled up and faster installation, (4) clean and causes less degradation in the products [28]. The improvement of coconut water shelflife can be done by microbial and enzyme filtration (not deactivation) [29].

The utilization of coconut water from a suitable variety, followed by cold sterilisation process that minimize the degradation of organoleptic properties and nutritional composition, may produce an isotonic drink product that needs, if any, the minimum amount of food additives.

\section{CONCLUSIONS}

The characterization of three varieties of coconut showed that Dwarf coconut water may be recommended as isotonic drink natural raw material that was the closest to the quality standard of isotonic drink, for future processing with cold sterilisation technology such as ultrafiltration.

\section{ACKNOWLEDGMENT}

The authors are grateful for the cooperation and assistance of the plantation managers and technicians of Experimental Plantation, Indonesian Industrial Crops Research Institute, Sukabumi, West Java, in exploring the varieties of coconut and collecting the coconuts for the study. 


\section{REFERENCES}

[1] B. Chavalittamrong, P. Pidatcha, and U. Thavisri, "Electrolytes, sugar, calories, osmolarity and $\mathrm{pH}$ of beverages and coconut water", Southeast Asian J Trop Med Public Health. 13: 427-31, 1982.

[2] S. Bahri, J. I. Sigit, T. Apriantono, and R. Syafriani, "Penanganan rehidrasi setelah olahraga dengan air kelapa, air kelapa ditambah gula putih, minuman suplemen dan air putih", Jurnal Matematika dan Sains, Vol. 17 Nomor 1, April 2012.

[3] M. Saat, R. Singh, R. G. Sirisinghe, and M. Nawawi, "Rehydration after exercise with fresh young coconut water, carbohydrate electrolyte beverage and plain water", J Physiol Anthropo. Appl Human Sci. 21:93-104, 2002.

[4] D. S. Kalman, S. Feldman, D. R. Krieger, and R. J. Bloomer, "Comparison of coconut water and a carbohydrate-electrolyte sport drink on measures of hydration and physical performance in exercise-trained men", Journal of The International Society of Sports Nutrition. 2012, 9:1.

[5] Minuman Isotonik. Badan Standarisasi Nasional. SNI 01-4452-1998. 1998.

[6] A. C. P. Duarte, A. A. Z Coelho and S. G. F Leite. "Identification of peroxidase and tyrosinase in green coconut water". Ciencia $y$ Tecnología Alimentari'a, 3(5), 266-270. 2002.

[7] M. P. Magalhaes, F. S. Gomes, R. C. D Modesta, V. M. Matta, and L. M. C. Cabral. "Conservation of green coconut water by membrane filtration”. Ciencia y Tecnologl'a Alimentarı'a, 25(1):72-77. 2005.

[8] K. Haynes, R. Bundang, O. Chu, C. Eichinger, D. S. Lineback, and A. D. Bolles. "Method for production of coconut water beverage and blended juice beverages with coconut water". US Patent. US 2004/0018285 A1. 2004.

[9] Food and Agriculture Organization. (2000) Press release: Coconut water as energy drink for joggers and athletes - First patent granted to UN Food Agency. [Online]. Available: http://www.fao.org/default.htm.

[10] S. I. Kailaku, A. N. A Syah, and I. Mulyawanti. "Perbaikan mutu minuman isotonik alami air kelapa dengan teknologi ultrafiltrasi", in Prosiding Lokakarya Nasional: Strategi Peningkatan Nilai Tambah Hasil Pertanian melalui Penerapan Teknologi Pascapanen dan Sistem Keamanan Pangan. Balai Besar Litbang Pascapanen Pertanian, 12 September 2006.

[11] D. S. Pandin. "Penanda DNA Untuk Pemuliaan Tanaman Kelapa (Cocos nucifera L.)". Perspektif Vol. 9 No. 1 / Juni 2010. pp 21- 35.

[12] M. Arsa. "Kandungan natrium dan kalium larutan isotonik alami air kelapa (Cocos Nucifera) varietas Eburnia, Viridis dan Hibrida", thesis. Program Magister Program Studi Kimia Terapan Program Pascasarjana Universitas Udayana Denpasar. 2011.

[13] T. C. Tan, L. H. Cheng, R. Bhat, G. Rusul, and A. M. Easa. "Composition, physicochemical properties and thermal inactivation kinetics of polyphenol oxidase and peroxidase from coconut (Cocos nucifera) water obtained from immature, mature and overly-mature coconut". Food Chem 142, p. 121-128. 2014.

[14] A. Apriyantono, D. Fardiaz, N. L. Puspitasari, Sedarnawi, and S. Budiyanto. Petunjuk Laboratorium Analisis Pangan. Departemen Pendidikan dan Kebudayaan, Direktorat Jendral Pendidikan Tinggi,
Pusat Antar Universitas Pangan dan Gizi. Institut Pertanian Bogor. 1989.

[15] D. Muchtadi. Petunjuk Laboratorium Evaluasi Nilai Gizi Pangan Departemen Pendidikan dan Kebudayaan. Direktorat Jenderal Pendidikan Tinggi. Pusat Antar Universitas Pangan dan Gizi. Institut Pertanian Bogor. 1989.

[16] N. Hidayati. 1992. Penentuan tiamin, riboflavin dan piridoksin dalam beras dengan HPLC secara serentak. Pusat Aplikasi Isotop dan Radiasi, Badan Tenaga Nuklir Nasional. [Online]. Available: http://digilib.batan.go.id/e-prosiding/File Prosiding/ Pertanian Peternakan /Hasil_Penelitian_1990-1992_PAIR/ Data_Artikel/ Nurhidayati -111.pdf. 1992.

[17] Standard Methods For The Examination of Water and Waste Water. 20th edition. American Public Health Association. 1998.

[18] S. Josephson. "Recovery Nutrition". NSCA's Performance Training Journal. Vol 2. No. 5. 2003.

[19] D. J. Casa, L. E. Armstrong, S. K. Hillman, S. J. Montain, R. V. Reiff, B. S. E Rich, W. O Roberts, and JA Stone. "National Athletic Trainers' Association Position Statement: Fluid replacement for athletes". J. Athletic Training 35(2):212-224. 2000.

[20] R. Murray R and J. Stofan. "Formulating Carbohydrate-Electrolyte Drinks for Optimal Efficacy" in J. R. Maughan and R. Murray (editor). Sport Drink. CRC Press. Boca Raton-London-New YorkWashington DC. 2001.

[21] T. Yawata. "Effect of $\mathrm{K}$ solution on rehydration in rats comparison w Na solution n water". Japanese Journal of Physiology, 40, 369381. 1990.

[22] J. W. H Yong, L. Ge, Y. F. Ng, and S. N. Tan. "The chemical composition and biological properties of coconut water". Molecules 14, 5144-5164. 2009

[23] A. Prades, M. Dornier, N. Diop, J. P. Pain. "Coconut water preservation and processing: a review". Fruits 67, 157-171. 2012.

[24] J. C. Jackson, A. Gordon, G. Wizzard, K. McCook, and R. Rolle "Changes in chemical composition of coconut (Cocos nucifera) water during maturation of the fruit". Journal of the Science of Food and Agriculture, 84, 1049-1052. 2004.

[25] C. E. LaClair and M. R. Etzel. "Ingredients and pH are key to clear beverages that contain whey protein". Journal of Food Science, 75(1), C21-C27. 2010.

[26] M. D. Purkayastha, D. Kalita, N. K. Mahnot, C. L. Mahanta. "Effect of L-ascorbic acid addition on the quality attributes of micro-filtered coconut water stored at $4{ }^{\circ} \mathrm{C}$ ". Innovative Food Science and Emerging Technologies 16: 69-79. 2012.

[27] L. A. Nakanoa, W. F. Leal Jr, D. G. C. Freitasb, L. M. C. Cabralb, E. M. Penhab, A. L. Penteadob, and V. M. Mattab. "Coconut water processing using ultrafiltration and pasteurization", in Proceeding of International Congress on Engineering and Food. National Technical University of Athens. Nov 2011.

[28] P. Fellows. "Food processing technology: principles and practice". Woodhead Publishing Limitted. CRC Press. Washington DC. 2000.

[29] Food and Agriculture Organization. (2007) Microfiltration process for cold sterilization of coconut water: technical details. [Online]. Available: http://www.fao.org/ag/magazine/9810/spot3add.htm. [Diakses 5 Maret 2014]. 